\title{
Os pretensiosos e endeusados papers
}

\author{
Senhor Editor:
}

Manifesto contrariedade em relação a este assunto esclarecendo, de início, que minhas ponderações têm nexo quase só com vivência na Faculdade de Medicina da Universidade de São Paulo e no Hospital das Clínicas que dela faz parte. Apenas ocasionalmente conheci fatos relacionados com o assunto em outros ambientes, mas percebo o que se passa com ele nas instituições citadas.

No âmbito da Infectologia ao qual dedico-me desde há muitos anos, estando com ele comprometido, desenvolvendo atividades assistenciais e de investigações científicas relacionadas com doenças infecciosas e parasitárias, como também desempenhando missões de assessoramento a órgãos governamentais que devem zelar pela saúde pública, as melhores contribuições estão divulgadas em prestimosas revistas nacionais. São resultados de estudos que permitem a adoção correta de providências sobretudo de naturezas epidemiológica, diagnóstica, terapêutica e preventiva. Tais colaborações respaldam atitudes regularmente adotadas em variados níveis, incluindo os oficiais a cargo dos Governos Federal, Estaduais e Municipais, ligados por vezes a surtos epidêmicos. Através de tais colaborações ficam propiciados subsídios fundamentais, caracterizando grande parte dos objetivos efetivos das pesquisas científicas. As matérias em questão não figuram habitualmente em periódicos estrangeiros e em quantidades maiores constituem elementos de ciência aplicada, só em menor número dizendo respeito a estudos acadêmicos.

Os que valorizam fanaticamente o que é impresso em revistas estrangeiras, com destaque para as inglesas e norte-americanas, salientam que elas adotam critérios rigorosos para selecionar os pedidos para publicações. Trata-se de opinião frágil, porquanto aqui vários periódicos científicos contam com criteriosos, competentes e respeitáveis Conselhos Editoriais, formados por profissionais cuidadosamente escolhidos. Ilustro isso citando, sem receio de equivocar-me, as Memórias do Instituto Oswaldo Cruz, a Revista do Instituto de Medicina Tropical de São Paulo, a Revista de Saúde Pública e a Revista da Sociedade Brasileira de Medicina Tropical. Assim, impõe-se desmistificar a equivocada ponderação por vezes usada pelos paperistas.
Meu comportamento é habitualmente pautado por humildade. Não obstante, agora vou deixar de lado essa compostura e mencionar diversas realizações científicas que concretizei, possibilitando elas quase que cotidianamente utilizações em tarefas assistenciais, sem terem feito parte de papers: investigações concernentes à estrongiloidíase (diagnóstico laboratorial; descrição de alterações clínico-radiológicas; tratamento; relato pioneiro da hiperinfecção), demonstração da transmissão do Trypanosoma cruzi por transfusão de sangue com a preconização de medidas preventivas, demarcação clínicolaboratorial-radiológica da fase aguda da doença de Chagas, sistematização dos tipos da toxoplasmose adquirida, desvendamento da forma tifoídica da toxoplasmose, permanente atualização quanto ao diagnóstico como também ao tratamento de parasitoses intestinais, além da revelação de três das seis modalidades alternativas de transmissão do Trypanosoma cruzi. Certamente são bem mais prestimosas na prática médica do que matérias meramente acadêmicas desprovidas de implicações aptas a gerar benefícios palpáveis. Ou então afiguram-se dotadas de conseqüências prestativas expressivamente superiores a papers apenas representativos de especulações até esdrúxulas.

É importante aduzir o desprezo freqüentemente demonstrado pela direção de determinadas revistas do Exterior por pedidos de pesquisadores de países subdesenvolvidos. Por outro lado, conheço restrições, temporárias ou não, à publicação de resultados de cientistas que não são do primeiro mundo, à espera de divulgação de dados congêneres obtidos por radicados nessas nações tidas como prioritárias.

Notei, em mais de uma oportunidade, confusões e ignorância por parte de julgadores estrangeiros aos quais houve solicitação de pareceres acerca de enfermidades tropicais.

Nunca deparei-me com marcantes trapaças científicas acolhidas pelos quatro veículos nacionais que nomeei. Porém, já estiveram incluídas em periódicos acolhedores de papers, tendo escapado à perspicácia de componentes dos Conselhos.

Endereço para correspondência: Prof Vicente Amato Neto. Alameda Casa Branca 559/7, Jardim Paulista, 01408-001 São Paulo, SP. 
É descartável a impressão de que não sou sistematicamente autor de papers. Tudo depende de circunstâncias, dos assuntos e de desejos de demais participantes.

A Comissão Científica dos Laboratórios de Investigação Médica do Hospital das Clínicas, da Faculdade de Medicina da Universidade de São Paulo, é exemplo de colegiado que tem fascínio pelos papers e não concede o mesmo valor a colaborações e produtividades de fato muito úteis. Repercussões injustas outrossim ocorrem em pleitos universitários ou de outras naturezas.

Os dirigentes das elogiáveis revistas nacionais, como as antes lembradas, precisam agir no sentido de evitar que fiquem colocadas em situação inferior, injustamente.

Bom senso, comedimento e maneira de proceder sem ortodoxismo colocarão o tema no lugar mais adequado, equilibrado e justo.

\section{Vicente Amato Neto}

